Article

\title{
An Analysis of Sustainability Integration in Business School Curricula: Evidence from Korea
}

\author{
Hannah Jun 1,*(D) and Seoyoung Moon ${ }^{2}$ (D) \\ 1 Graduate School of International Studies, Ewha Womans University, Seoul 03760, Korea \\ 2 Graduate School of Public Administration, Seoul National University, Seoul 08826, Korea; \\ symoon0604@snu.ac.kr \\ * Correspondence: hannahjun@ewha.ac.kr
}

Citation: Jun, H.; Moon, S. An Analysis of Sustainability Integration in Business School Curricula: Evidence from Korea. Sustainability 2021, 13, 2779. https://doi.org/ $10.3390 /$ su13052779

Academic Editor: Renate Wesselink

Received: 7 February 2021

Accepted: 3 March 2021

Published: 4 March 2021

Publisher's Note: MDPI stays neutral with regard to jurisdictional claims in published maps and institutional affiliations.

Copyright: (c) 2021 by the authors. Licensee MDPI, Basel, Switzerland. This article is an open access article distributed under the terms and conditions of the Creative Commons Attribution (CC BY) license (https:// creativecommons.org/licenses/by/ $4.0 /)$.

\begin{abstract}
Given the growing importance of corporate sustainability in the academic literature and in practice, this study investigates to what extent business schools in South Korea have been reflecting sustainability-linked themes in the curriculum. Based on a review of 20,507 course syllabi from ten sample universities between 2013 and 2019, our findings show an increase in the absolute number and proportion of sustainability-linked courses in Korean business schools, increasing from $12.9 \%$ of total courses in 2013 to $14.7 \%$ in 2019 . The most prominent sustainability keywords were "ethics" and "corporate social responsibility," with most courses reflecting sustainability keywords by allocating a few weeks to sustainability issues (sustainability-inclusive) rather than sustainability serving as the major theme of the course (sustainability-focused). In terms of degree program, sustainability-linked courses accounted for nearly $15 \%$ of total courses at the undergraduate and Master of Business Administration (MBA) levels, respectively, and just 7\% of graduate (Master's/Ph.D.) programs in Business Administration. While our findings suggest overall progress in incorporating sustainability themes in business schools, course offerings are fragmented and generally focus on a narrow concept of ethics rather than constituting a comprehensive curriculum that weaves sustainability throughout functional majors.
\end{abstract}

Keywords: business school curriculum; Korea; sustainability; sustainability education; sustainability integration

\section{Introduction}

When it comes to business programs, the rationale for incorporating sustainability themes into the curriculum has been built on decades of discourse on business ethics, corporate social responsibility (CSR) and sustainability on the one hand [1,2], and acute awareness that business practitioners play a crucial role in shaping the global sustainability agenda on the other [3]. This push to embed sustainability, or "development that meets the needs of the present without compromising the ability of future generations to meet their own needs" [4] (p. 41), has accelerated in recent years with the implementation of initiatives such as the UN Sustainable Development Goals (SDGs).

However, while many studies affirm the importance of blending sustainability in higher education and even offer frameworks and tools to incorporate sustainability in university culture and curricula [5-9], there is little recent research that examines the state of sustainability integration in higher education-particularly for Asian economies such as South Korea. This includes an exploration of core sustainability themes and keywords in business courses over time, as well as the depth of sustainability integration. In other words, we lack clear evidence that universities as a whole (and business programs in particular) have been substantively reflecting sustainability in the curriculum in-line with heightened rhetoric on its importance. Furthermore, as the literature on sustainability curricula suggest meaningful differences by region $[10,11]$, further study may help uncover these nuances more effectively. 
To fill this gap, this study provides a unique, in-depth review of the state of sustainability education at Korean universities, both for undergraduate and graduate (M.A./Ph.D. and Master of Business Administration (MBA)) business programs, between 2013 and 2019 . Findings from this study should help us determine whether and to what extent business school curricula have incorporated sustainability over time, and what improvements can be made to embed core themes going forward.

\section{Literature Review}

Corporations have been at the forefront of both criticism and innovation in addressing environmental issues and social inequalities. When it comes to the environment, firms and industry have been major culprits of pollution and environmental degradation [12], while at the same time the private sector has been capable of achieving remarkable technological innovation facilitated by the hyper-competitive market in which firms operate. Big business has also been blamed for contributing to growing social inequalities (such as unequal wealth distribution), yet it also serves as an important source of employment and investment around the world-particularly in cases where the public sector is either incapable or unwilling to do so. It should come as no surprise, then, that business schools, as pivotal training grounds for future business leaders, have also faced similar scrutiny. At its best, the university may be able to facilitate the linkage between civic values and civic behavior [13] At the same time, business schools in particular have been criticized for contributing to corporate corruption, as "by propagating ideologically inspired amoral theories, [they] have actively freed their students from any sense of moral responsibility" [14] (p. 75). So, just as we see an acceleration of emphasis on sustainability in corporate strategy and operations, there is continued demand for critical analysis of sustainability issues in traditional business programs.

Within business schools, several sustainability-related keywords have been incorporated fairly broadly. These include, among others, business ethics, corporate social responsibility, social value, environmental impact, sustainable finance and sustainability. Although these concepts share the idea that business activities can and perhaps should go beyond purely economic considerations, the range of terminologies suggest meaningful distinctions and often reflect the preferred lingo of the times. When it comes to teaching business ethics, for example, concerns about potential mismatches between rhetoric and the reality of business ethics education began in earnest in the 1970s and 1980s [15]. This has included pedagogical debates, including whether business ethics can actually be taught [16-18] and how better to incorporate business ethics in the curriculum [19-21]. An additional concern voiced early on was that business ethics was perceived as an "in" subject that reflected "ethical chic" rather than a serious discussion about crafting an effective organization ethic based on optimizing benefits for all parties [22] (p. 15). Furthermore, as ethics goes beyond issues of legality, practical concerns have included how to determine what is acceptable and "right" - an arguably normative framework — when dealing with different and often competing concepts of ethical business. This is in addition to the challenge of finding ways to implement this understanding within the organization. At the same time, there has been evidence of business ethics courses taking root in business schools outside of the United States, such as the United Kingdom [23], although research on Asian economies remains scarce. While one exception is an analysis of the impact of teaching business ethics in Korea with undergraduate major students from over two decades ago [24], larger-scale studies that examine the depth of integration of sustainability-related education in Korean business schools are absent.

In a similar vein, CSR has attempted to understand the scope of a firm's responsibilities (both financial and non-financial). In the narrowest sense, this has included corporate contributions and philanthropy, or a firm's "discretionary" responsibilities [25]. However, the CSR literature has also encompassed strategic CSR (as opposed to "altruistic" CSR), which examines ways that corporate social responsibility can boost financial performance. Some empirical mechanisms that have been identified include enhanced firm reputation, 
stakeholder reciprocation, risk mitigation and improved innovation capacity [26]. Blending CSR into business schools has also been fairly widespread, with examples including CSR education in Europe [27] as well as CSR in management education in Spanish universities [28,29]. In addition, extensions of CSR have included creating shared value (CSV), or "policies and operating practices that enhance the competitiveness of a company while simultaneously advancing the economic and social conditions in the communities in which it operates" [30] (p. 6). While not without its critics, particularly with regards to the concept's originality and perceived silence on tensions inherent in business activities [31], CSV has been a topic of interest in the business school curriculum as well as among practitioners [32]. Lastly, with many multinational corporations also having a sizeable presence in developing economies, CSR research and teaching has also reflected the role of corporations in the development context [33,34], including the implementation of more sustainable supply chains.

With regard to non-economic externalities generated by corporations, two areas that have been given extensive attention are social and environmental impacts. Aside from CSV, which has focused more on channeling some resources from traditional for-profit firms to address external needs, social enterprises and ventures have been more explicit in addressing social needs by pivoting the firm's mission and leveraging resources to simultaneously generate financial and social impact. While a large part of the curriculum in leading business schools [35], greater interest in social enterprises in South Korea was prompted by the enactment of the Social Enterprise Promotion Act in 2007, spearheaded by the Ministry of Employment and Labor (MOEL). Defined by the Korea Social Enterprise Promotion Agency (KoSEA) as "a company or organization which performs business activities while putting priority on the pursuit of social purposes" [36], social enterprises have been touted as a solution to address unemployment among the youth and disadvantaged. As such, we may anticipate that business school curricula may pay similar attention to social enterprises and ventures as alternative business models.

Environmental impacts have also received significant attention in the business literature and business school curriculum. Nearly 30 years ago, academics already began chiming that business schools should not only "catch up" to environmental considerations (from manufacturing processes to the promotion of environmentally friendly packaging), but that they should "try and position themselves on the cutting edge" [37] (p. 3). Early studies on introducing environmental management courses in MBA programs found that students were more knowledgeable about the environment, expressed more concerns about the environment, and were more action-oriented after taking the course [38], with calls for "green marketing" and "green advertising" in the marketing curriculum also accelerating at this time $[39,40]$. More recent research has found that business administration and accounting students, while having limited knowledge about social and environmental accounting, had a keen interest in learning about this area and had already internalized the importance of accountants sharing issues such as a firm's environmental footprint to external stakeholders [41]. Thus, given ample evidence of blending environmental issues in business school programs, we may expect business school curricula to continue addressing environmental/green management, environmental sustainability, business and climate change, eco-friendly processes as well as environmental impact.

When it comes to finance, we have seen a rich discussion in the academic literature regarding socially responsible investment (SRI) [42-45] as well as environmental, social and governance (ESG) issues [46-48]. However, compared with other sustainability-related keywords, sustainable finance has not been as noticeably incorporated in the curriculum and the academic literature on its inclusion in business schools remains largely silent. While this may mirror the relatively late introduction of sustainable finance terminology in the literature and practice, we can expect business schools to develop related curricula given the rapid growth of such investments and practical implications to managers. On the other hand, "sustainability" and "sustainable business practices" as keywords have been increasingly prominent in the business school curriculum. There have been concerted efforts to go 
beyond concepts such as "green marketing" and meaningfully integrate sustainability in business schools, particularly for marketing courses [49], which cover not only environmental issues, but also social and financial sustainability. This trend has been encouraged by social and environmental reporting initiatives, such as the Global Reporting Initiative (GRI) [50] and advocacy efforts from organizations such as the Association to Advance Collegiate Schools of Business International [51,52]. Studies on the importance of ethics, CSR and sustainability have also shown a trend towards the inclusion of sustainability-related courses by utilizing experiential learning and immersion techniques [53], and in recent years, sustainability has emerged more visibly with the launch of the 2030 Agenda, or SDGs. Some examples of this include case studies in implementing sustainability management education as part of a model for business schools contributing to the SDGs [54].

Separately, there has been greater acknowledgment that sustainability and responsible business practices are not limited to specific courses but should be woven throughout the curriculum. As summarized by David Dunne, director of the Gustavson School of Business at the University of Victoria, the task is to "weave sustainability and technology and innovation into every course so that the finance professor is not teaching (students) how to make a million dollars but is teaching finance for impact and looking at how sustainable investment funds work" [55]. As core sustainability themes touch on all major corporate functions, the impact to business school curricula is clear: sustainability should be reflected across functional concentrations such as business strategy, operations, supply chain management, human resource management, marketing, accounting and finance. However, to what extent have sustainability-related themes actually been taught in business schools and have there been any noticeable changes over time? The following sections attempt to answer these questions and, by so doing, provide a meaningful contribution to the literature.

\section{Research Design}

In this section, we briefly outline the approach used to select sample business schools and collect data for this study. We then describe the analysis conducted to investigate to what extent business schools in South Korea have integrated sustainability-linked themes into the curriculum.

\subsection{Sample Selection}

As an initial sample for this study, we selected the top 30 universities ranked in the 2019 business school assessment by Hankyung Business. Hankyung Business is an authoritative, weekly newspaper published in South Korea that covers domestic and international economic issues and industrial trends. Since 2008, it has conducted an annual, nationwide evaluation of business schools by surveying human resource managers from 200 to 300 companies in Korea on the basis of nine dimensions: (1) professional relevance of education; (2) organizational adaptability; (3) organizational cohesion; (4) potential to develop; (5) creativity; (6) globalized curriculum; (7) diligence and responsibility; (8) preference for new employee recruitment; and (9) admission recommendation. Rankings for each dimension are added together and an overall ranking is determined. The rationale for beginning with the top 30 universities includes a higher likelihood of maintenance of and public access to past course lists and syllabi, as well as precedence from previous literature that has examined sustainability integration in highly-ranked business schools [53]. Regarding the latter point, part of this may be due to these universities having the resources and incentive to respond quickly to reflect newer concepts in the curriculum in order to meet the needs of the marketplace.

From the initial sample, we checked whether the universities allowed public access to the list of courses and respective syllabi during the period of analysis (2013-2019). The period between 2013 and 2019 was chosen as 2019 was the most recent full year available at the time of this study's analysis, and a preliminary investigation revealed that most schools kept an online record of course syllabi from 2013 at the earliest. We then checked 
whether the sample universities had both a graduate program in Business Administration (or Master of Business Administration (MBA) program) in addition to an undergraduate program in Business Administration. Because previous studies on sustainability integration in business schools tended to examine either graduate or undergraduate programs and have not provided an in-depth analysis of potential disparities between these two groups of programs, we hoped to provide a strong foundation for comparative analysis in this study. In the end, of the top 30 universities in our initial sample, a total of 10 universities met the above criteria and were selected as the final sample pool for this study.

\subsection{Data Collection Procedure and Key Sources}

Each university's official website and respective course syllabi were used as primary data sources for this study. A total of seven years (2013-2019) was set as the timeframe for this research in order to investigate the trend of sustainability course offerings over time. The course data for 14 consecutive semesters (from spring semester 2013 to fall semester 2019) was collected between June and October 2020 for this study in accordance with the following two procedures (Figure 1).

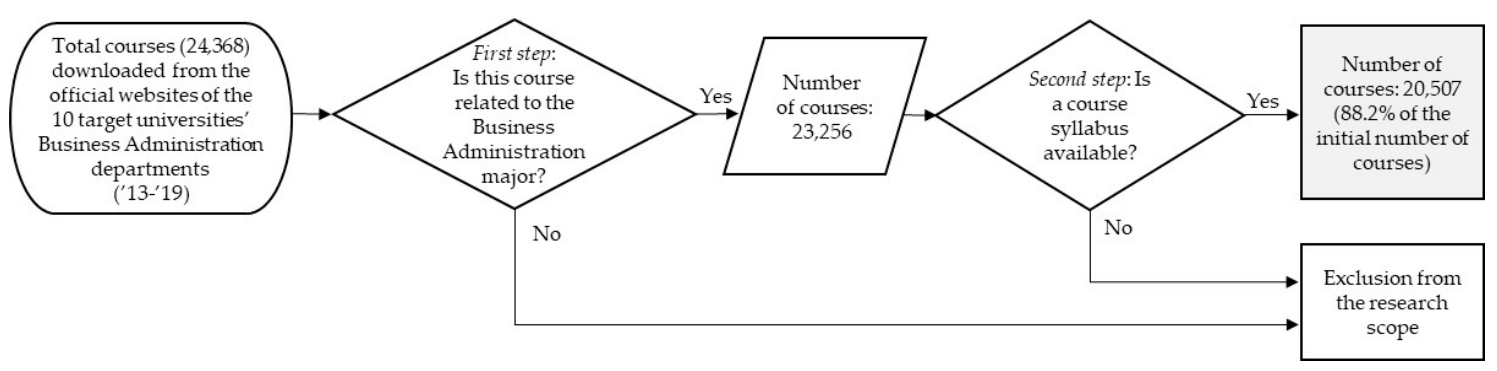

Figure 1. Data collection procedure flow chart.

First, we carried out an exhaustive examination of course lists and syllabi of the target universities' Business Administration departments from their official websites and downloaded all course syllabi. Liberal arts courses were excluded and only Business Administration major courses were included in the research scope. The total number of courses collected from the 10 sample universities was 23,256 . After this initial data collection, the following information for each course was organized as follows: university name, course year, course term, degree program (undergraduate/graduate/MBA program), course number, lecture number, course title, instructor, and availability $(\mathrm{O} / \mathrm{X})$ and contents of a course syllabus. Both Korean and English language syllabi were included in the analysis.

Second, of the total number of courses accounted for in the first stage $(23,256)$, we excluded courses in which a syllabus was not available. The rationale for this was without a syllabus, we did not have objective criteria from which to gauge whether (and to what extent) sustainability concepts were actually included as part of the course. The total number of courses in which a syllabus was available was 20,507 (88.2\% of the initial number of courses). While the format of a course syllabus was different for each university, common elements across sample universities included: (1) course objectives and description; (2) weekly schedule; and (3) references. One point of note is there were some cases in which course objectives included the university's philosophy or mission, such as "the cultivation of management ethics and social responsibility." While this explicit mention may be seen as a positive trend in that some universities have taken a broad-based approach to highlight the importance of ethics and arguably sustainability, as this study aimed to see whether sustainability was actually dealt with as a substantive part of the course, contents related to a university's philosophy or mission in the course objective of a syllabus were excluded. Thus, only sustainability contents related specifically to the course were included in the scope of analysis. 


\subsection{Method of Data Analysis \\ 3.3.1. Identification of Sustainability Courses}

Before the actual analysis, sustainability courses among the total number of courses with a syllabus were identified following a keyword search. To begin with, this study assumed that sustainability issues were addressed in class if sustainability keywords appeared in a course syllabus. Representative keywords used during this procedure were selected by this study's initial literature review, with related keywords added through a review of relevant articles, newspapers and course names. As shown in Table 1, we grouped highly relevant keywords into a keyword pool of six categories which are distinctive by theme. When writing the analysis results, each keyword category name was used in the following shorthand form: ethics = eth; CSR = CSR; social value = SV; environment $=$ env; finance = fin; sustainable business = SB. If "business ethics" and /or "management ethics" keywords were included in a course syllabus, for example, this course was included in the "ethics" ("eth") category. As suggested by our literature review, we acknowledged that there may be potential for overlap between representative and related keywords. For example, previous literature has often lumped keywords used in our framework together, such as business ethics, CSR and sustainability [53]. This implies that there are some similar elements among keywords and making definitive, clear-cut distinctions may be challenging at best. At the same time, given the rich debate in the literature and in practice for each of the six representative keywords in our framework, we took efforts to distinguish between these keywords and provide additional analysis of keyword frequency to supplement our findings.

Table 1. Keyword classifications for analysis. ESG: environmental, social and governance.

\begin{tabular}{|c|c|c|c|c|c|}
\hline $\begin{array}{l}\text { Ethics } \\
\text { "eth" }\end{array}$ & $\begin{array}{c}\text { CSR } \\
\text { "CSR" }\end{array}$ & $\begin{array}{l}\text { Social Value } \\
\text { "SV" }\end{array}$ & $\begin{array}{l}\text { Environment } \\
\text { "env" }\end{array}$ & $\begin{array}{l}\text { Finance } \\
\text { "fin" }\end{array}$ & $\begin{array}{c}\text { Sustainable } \\
\text { Business "SB" }\end{array}$ \\
\hline Ethics & Business and society & Social value & Env. management & ESG & Sustainability \\
\hline Business ethics & CSR & Social enterprise & Green management & Social finance & Sustainable business \\
\hline $\begin{array}{c}\text { Ethical } \\
\text { management }\end{array}$ & Sustainable supply chain & $\begin{array}{c}\text { Social } \\
\text { entrepreneurship }\end{array}$ & $\begin{array}{l}\text { Environmental (env.) } \\
\text { sustainability }\end{array}$ & $\begin{array}{l}\text { Socially responsible } \\
\text { investing (SRI) }\end{array}$ & $\begin{array}{l}\text { Sustainable } \\
\text { management }\end{array}$ \\
\hline Management ethics & $\mathrm{CSV} /$ shared value & Social venture & Climate change & Impact investing & \\
\hline & Philanthropy & Social economy & Eco-friendly & & \\
\hline & $\begin{array}{c}\text { Social responsibility } \\
\text { Dev. Cooperation }\end{array}$ & Sharing economy & Env. value & & \\
\hline
\end{tabular}

During this process, we searched course titles and syllabus contents by using selected keywords in Korean as well as in English. Keyword search results were checked twice to ensure accuracy. This review was necessary because several keywords referred to different topics based on its unique context. For example, "business ethics" in a course syllabus can be interpreted as sustainability contents, while "academic ethics" (with regards to the course's plagiarism policy, for example) would not be considered substantive sustainability contents even though it contains the same word, "ethics." Based on this analysis, among courses with a syllabus $(20,507)$, the total number of sustainability-related courses over the seven-year period totaled 2880 (14.0\%).

\subsubsection{Units of Analysis}

In this study, sustainability course offerings were analyzed according to the following three units of analysis: (1) keywords; (2) sustainability course classifications; and (3) degree programs.

First, a keyword analysis of sustainability course offerings was conducted. This is to understand what sustainability issues have been predominantly addressed in courses offered among sample business schools during the period of analysis. We first assigned a unique keyword code for each sustainability course. The reason for this is that in many cases, multiple sustainability keywords were addressed in one course. If we conducted a simple tally of keywords, this would mean that the total number of keywords addressed 
would be greater than the number of courses in this study. To prevent confusion, a unique keyword was assigned for each course to keep track of what combination of sustainability keywords was addressed. Using this method, if a specific sustainability keyword was covered in a course, the number " 1 " was assigned to the corresponding keyword category (see Table 1). If a course syllabus did not include a keyword that corresponded to a specific sustainability keyword category, the keyword category was given the number " 0 ". After determining the six-digit designation, numbers assigned to each sustainability keyword category were concatenated into a single keyword combination character. For example, if the "Ethics, CSR, Social Value, Environment, Finance, Sustainable Business" keyword categories were given the numbers " $1,1,0,0,0,0$ ", respectively, these numbers were connected and incorporated into one character, "110000." This unique keyword code was then converted into an abbreviated form of corresponding keyword categories (e.g., $110000 \rightarrow$ eth.CSR) and used in the results of the analysis.

Second, sustainability course offerings were also analyzed according to sustainability course classifications. The reason for analyzing courses by classification was to determine whether sustainability issues were substantively covered in the course and to what extent these issues were explored. For this study, we classified sustainability course offerings into three sustainability course types: (1) sustainability-focused; (2) sustainability-inclusive; and (3) sustainability-descriptive courses. According to the Sustainability Tracking, Assessment and Rating System (STARS) technical manual developed by the Association for the Advancement of Sustainability in Higher Education (AASHE), sustainability course offerings consist of "sustainability-focused courses" and "sustainability-inclusive courses," of which sustainability-focused courses refer to courses in which "the course title or description must indicate a primary and explicit focus on sustainability," while a sustainability-inclusive course is "not explicitly focused on sustainability," but "incorporates a unit of module on sustainability or a sustainability challenge, includes one or more sustainability-focused activities, or integrates sustainability challenges, issues, and concepts throughout the course" in the course description or rationale provided in the course inventory [56] (AC-01 pp. 5-6).

In this manual, however, there are no objective guidelines on distinguishing between sustainability-focused and sustainability-inclusive courses or ascertaining whether sustainability-related themes are explicitly addressed in the course. Therefore, this study added a new concept ("sustainability-descriptive courses") to assess whether sustainabilityrelated issues are substantively covered. While we referred to the concepts and definitions of sustainability-focused and sustainability-inclusive courses presented in the STARS manual, this study set the following objective criteria to distinguish among sustainabilityfocused, sustainability-inclusive and sustainability-descriptive courses (Figure 2).

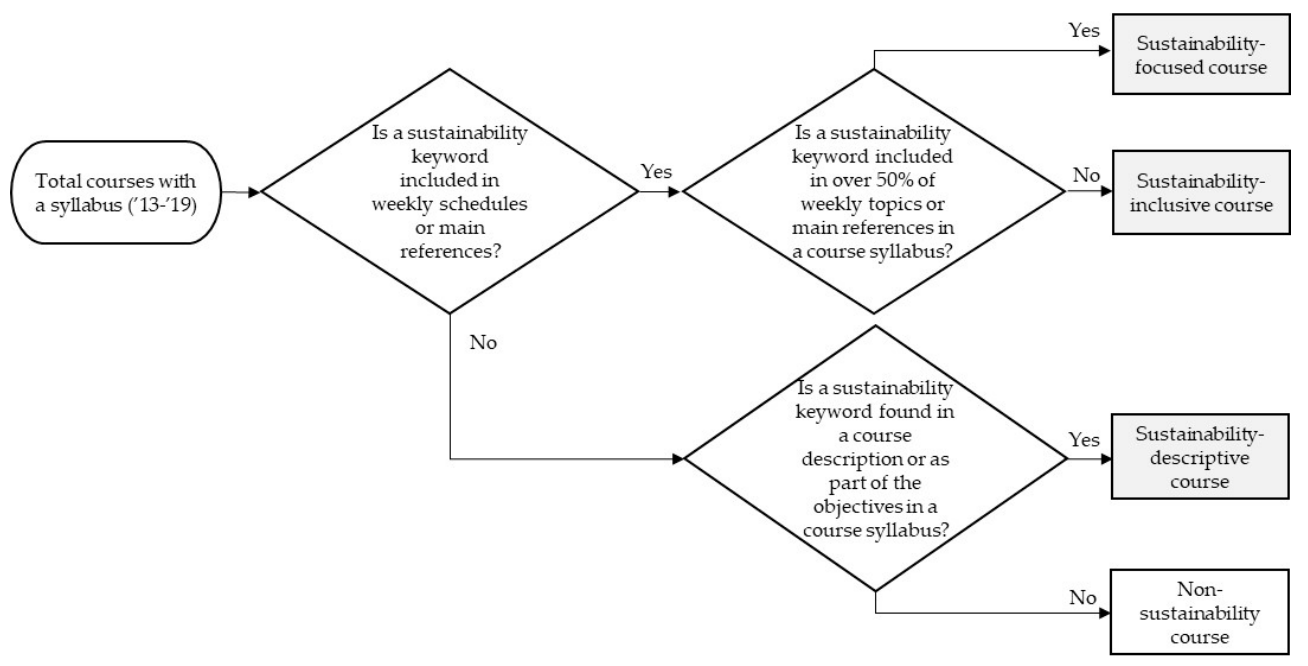

Figure 2. Criteria for sustainability course classifications. 
To count as a sustainability-focused course, a sustainability keyword must be included in over $50 \%$ of weekly topics or main references in a course syllabus. The reason for setting this $50 \%$ threshold as a reference point is that if a course deals with sustainability issues for more than one-half of the semester, we can judge that the sustainability issue was a predominant topic for that course. For example, a "Business Ethics" course in which weekly lectures are given on a topic of business ethics was classified as sustainability-focused. To count as a sustainability-inclusive course, a sustainability keyword must account for at least one week but less than $50 \%$ of weekly subjects or main references in a course syllabus. For example, a "Marketing Principles" course which deals with "marketing ethics" as one weekly topic was considered a sustainability-inclusive course. Lastly, to count as a sustainability-descriptive course, sustainability keywords would not be included in weekly schedules, but keywords would be found in a course description or as part of the objectives in a course syllabus. For example, a "Financial Statement Analysis" course in which no sustainability keywords were mentioned on the weekly schedule but included "to appreciate the implications of business ethics, CSR and the sustainability of business practices" as one of the course objectives in the course syllabus, was regarded as a sustainability-descriptive course.

Third, sustainability course offerings were analyzed based on degree program. This was to check which areas of the Business Administration curriculum (such as introductory, academic and practical subsets) the number of sustainability courses may have changed each year. This study classified degree programs for the Business Administration major into undergraduate, graduate (M.A./Ph.D.) and MBA programs. Based on the nature of the degree program, we can expect distinctive characteristics of respective courses to surface. For example, while undergraduate programs may focus more on basic and introductory course offerings, graduate programs may focus more on academic and advanced courses while MBA program courses may focus on practical and trending topics in Business Administration.

In the next section, we present a discussion of key findings as it relates to whether and to what extent sustainability themes have been reflected in course offerings by year. In addition, we provide a detailed analysis of characteristics of sustainability course offerings in accordance with the three units of analysis: sustainability course keywords, classifications and degree programs.

\section{Key Findings and Discussion}

\subsection{Total Sustainability Courses}

Over the period of analysis (from 2013-2019), the number of sustainability courses with a syllabus totaled 2880 , which represents $14.0 \%$ of total courses with a syllabus. By year, sustainability courses as a percentage of total courses with a syllabus increased from $12.9 \%$ in 2013 to $14.7 \%$ in 2019. As shown in the rightmost column of Table 2, it was difficult to articulate a distinct trend in the rate of change of sustainability courses to total courses by year. For example, in 2015 and 2018, the total number of courses increased more rapidly than the number of sustainability courses, while in other years the number of sustainability courses increased at a faster rate than total courses with a syllabus. This suggests that in addition to an increase in the total number of courses, other factors affected the growth in sustainability course offerings over the period of analysis. We summarize overall trends of sustainability course offerings among our sample business schools for the seven-year period (from 2013-2019) in Table 2. 
Table 2. Annual trend of sustainability courses in Korean business programs.

\begin{tabular}{|c|c|c|c|c|}
\hline Year & $\begin{array}{l}\text { Total Number of Courses } \\
\text { with a Syllabus (A) }\end{array}$ & $\begin{array}{l}\text { Number of Sustainability } \\
\text { Courses (B) }\end{array}$ & $\begin{array}{l}\text { Proportion of Sustainability } \\
\text { to Total Courses (B/A) }{ }^{1}\end{array}$ & $\begin{array}{l}\text { Rate of Change }{ }^{3} \\
\qquad(\triangle B / \triangle A)^{2}\end{array}$ \\
\hline 2013 & 2905 & 374 & $12.9 \%$ & $\mathrm{~N} / \mathrm{A}$ \\
\hline 2014 & 2885 & 399 & $13.8 \%$ & 9.7 \\
\hline 2015 & 2970 & 390 & $13.1 \%$ & 0.8 \\
\hline 2016 & 2882 & 404 & $14.0 \%$ & 1.2 \\
\hline 2017 & 2903 & 433 & $14.9 \%$ & 9.9 \\
\hline 2018 & 3018 & 448 & $14.8 \%$ & 0.9 \\
\hline 2019 & 2944 & 432 & $14.7 \%$ & 1.5 \\
\hline Total ('13-'19) & 20,507 & 2880 & $14.0 \%$ & $\mathrm{~N} / \mathrm{A}$ \\
\hline
\end{tabular}

${ }^{1}$ Proportions for sustainability courses to total courses with a syllabus were rounded to one decimal place. ${ }^{2} \triangle \mathrm{A}=(($ total number of courses with a syllabus in [n] year) — (total number of courses with a syllabus in [n -1$]$ year))/total number of courses with a syllabus in $(n-1)$ year; $\triangle B=(($ total number of sustainability courses in [n] year) — (total number of sustainability courses in [n -1$]$ year $)) /$ total number of sustainability courses in $(n-1)$ year. ${ }^{3} \mathrm{~A}$ rate of change over 1 signifies that the change in the number of sustainability courses is greater than that in the number of total courses with a syllabus for that year. The opposite is true if the rate is under 1.

As presented in Figure 3, a trend line for the proportion of sustainability course offerings for our period of analysis indicates a positive slope $\left(\beta: 0.0023, R^{2}=0.5894\right)$, reflecting an increasing trend in the percentage of sustainability courses out of total courses. In this respect, our analysis adds a meaningful contribution to the academic literature by supporting empirically that business school programs have been incorporating more sustainability themes in the curricula over time in-line with rhetoric on its importance.

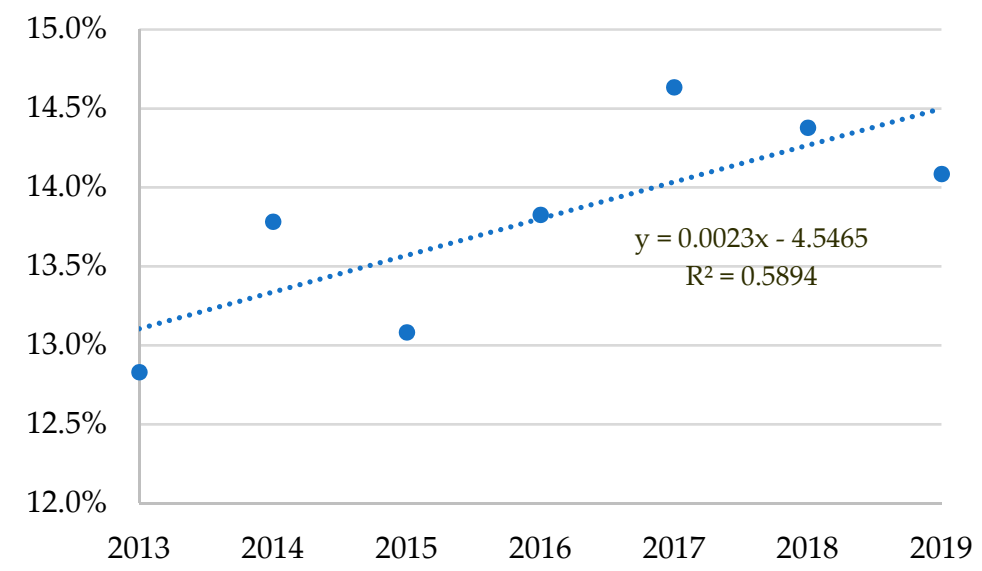

Figure 3. Trend line for the proportion of sustainability course offerings by year.

\subsection{Keyword Analysis of Sustainability Courses}

In Figure 4, we highlight the most frequently covered sustainability keyword codes over our period of analysis. Of these keyword codes, most of the top five sustainability keyword codes were single keywords (for example, "eth," "CSR," "SV" and "SB"), with sustainability courses that incorporated these five keyword codes accounting for $86.7 \%$ of all sustainability courses during the seven-year period. Noticeably, about one-half of all sustainability courses $(49.4 \%)$ contained the single "eth" (ethics) keyword code. While we found that the two keywords "eth" and "CSR" were often dealt with together in the same class ( $15.9 \%$ of all sustainability courses), other keywords were rarely covered together. This suggests that the approach to integrating sustainability issues in the business curriculum has been fragmented rather than holistic, reflected by the focus on specific keywords (particularly ethics) rather than linking key themes and concepts together. In addition, while an earlier review of the literature suggested a rich history of blending environmental issues into the business school curriculum, the number of courses which incorporated corporate environmental impacts in our study was noticeably low (the single "env" keyword accounted for just $1.7 \%$ of sustainability-linked courses in our analysis). 
This may suggest that Korean business programs lag behind global business schools in addressing environmental impacts in the curriculum.

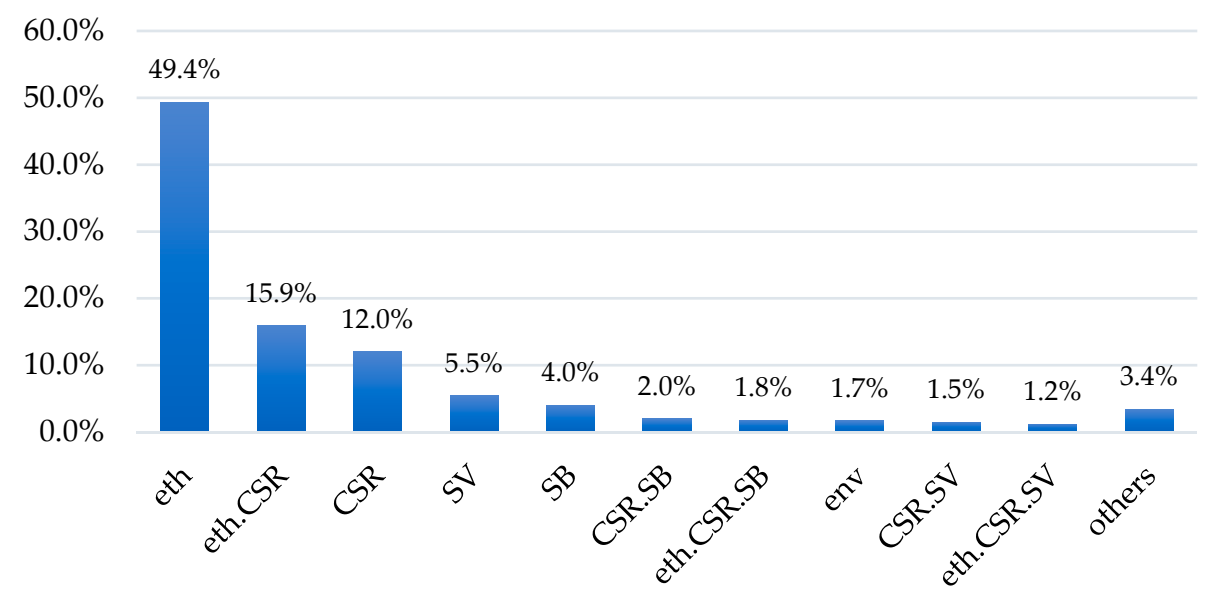

Figure 4. Top 10 sustainability keyword codes (from 2013-2019). Note: proportions for the top 10 sustainability keyword codes were rounded to one decimal place.

Based on our analysis, we found years in which the proportion of sustainability keyword codes covered changed significantly (see Appendix A). When this proportion increased or decreased, the number of sustainability courses per keyword code also changed in the same direction. For example, the proportion of courses which reflected the "SV" keyword code increased roughly two-fold from $5.8 \%$ in 2018 to $11.6 \%$ in 2019 . At the same time, the proportion of courses incorporating "eth" and "eth.CSR" keyword codes decreased from $47.3 \%$ and $17.0 \%$ in 2018 to $45.4 \%$ and $14.6 \%$ in 2019 , respectively, suggesting shifts in terminology usage over time. In addition, while the proportion of courses which included "SB" (sustainable business) and "eth.CSR" (ethics/CSR) keyword codes increased from $3.0 \%$ and $14.3 \%$ in 2017 to $6.3 \%$ and $17.0 \%$ in 2018 , respectively, the proportion of courses dealing with the "eth" keyword code decreased from $51.5 \%$ to $47.3 \%$ during the same period.

\subsection{Analysis of Sustainability Course Classifications}

Trends in sustainability-focused, sustainability-inclusive and sustainability-descriptive courses among sustainability courses offered at our sample business schools are presented in Figure 5. Between 2013 and 2019, 84.5\% of sustainability courses dealt with sustainability issues for at least one week in class (representing the sum of sustainability-focused and sustainability-inclusive courses), with $10.2 \%$ of total sustainability courses incorporating sustainability issues as a major theme for more than one-half of the semester (sustainabilityfocused). Most sustainability courses $(74.3 \%)$ covered sustainability content for at least one week, but for less than $50 \%$ of weekly subjects or main references (sustainability-inclusive). Over the seven-year period, $15.5 \%$ of sustainability courses only dealt with sustainability issues in the course objectives or syllabus description (sustainability-descriptive). In-line with previous research that has highlighted the importance of examining course contents in understanding curricular intent [57], illustrative texts taken from sample curricula for sustainability-focused,-inclusive and -descriptive courses are presented in Appendix B. 


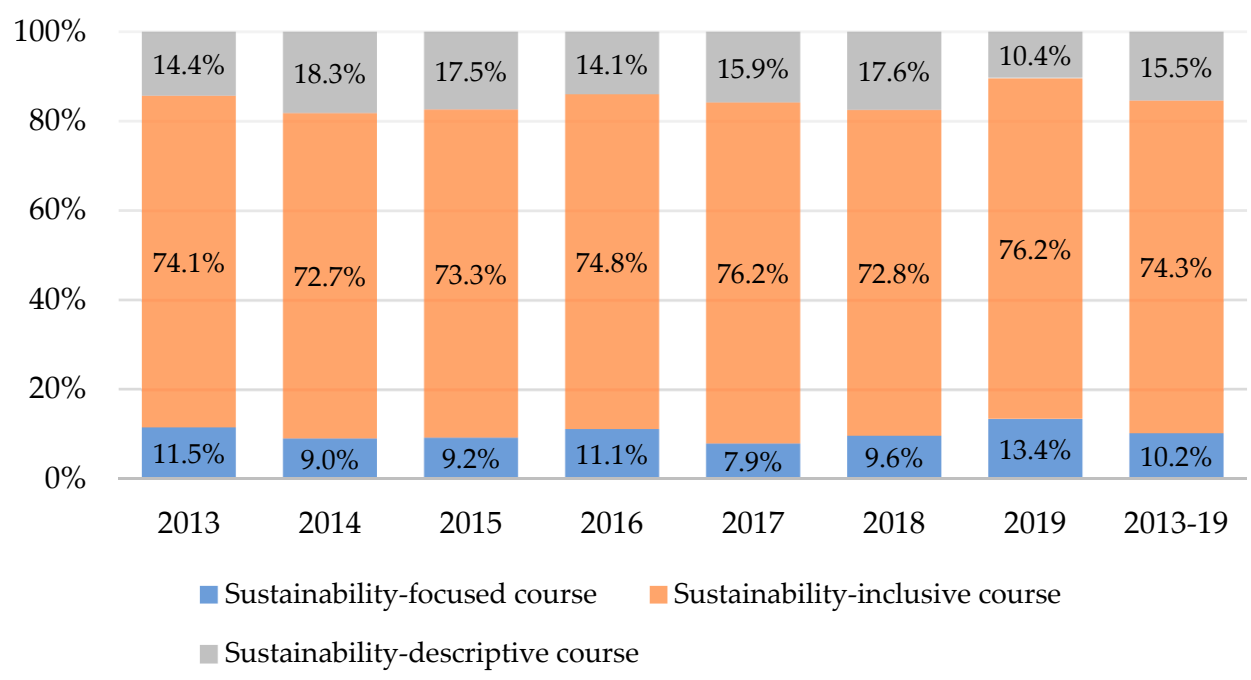

Figure 5. Annual trends in sustainability-focused, -inclusive and -descriptive courses. Note: proportions for sustainability-focused, -inclusive, and -descriptive courses were rounded to one decimal place.

As shown in Figure 6, trend lines for the proportion of sustainability-focused courses $\left(\beta: 0.002, R^{2}=0.0522\right)$ and sustainability-inclusive courses $\left(\beta: 0.0033, R^{2}=0.2344\right)$ out of total sustainability courses for the seven years exhibited a positive slope, indicating an increasing trend in proportions over time. On the other hand, we saw a negative slope $\left(\beta:-0.0053, R^{2}=0.1752\right)$ in the trend line for the proportion of sustainability-descriptive courses. Thus, based on our sample, we find evidence of the more conscious integration of sustainability themes into the curriculum as the proportion of sustainability-focused and -inclusive courses increased while the proportion of more superficial sustainabilitydescriptive courses decreased between 2013 and 2019.

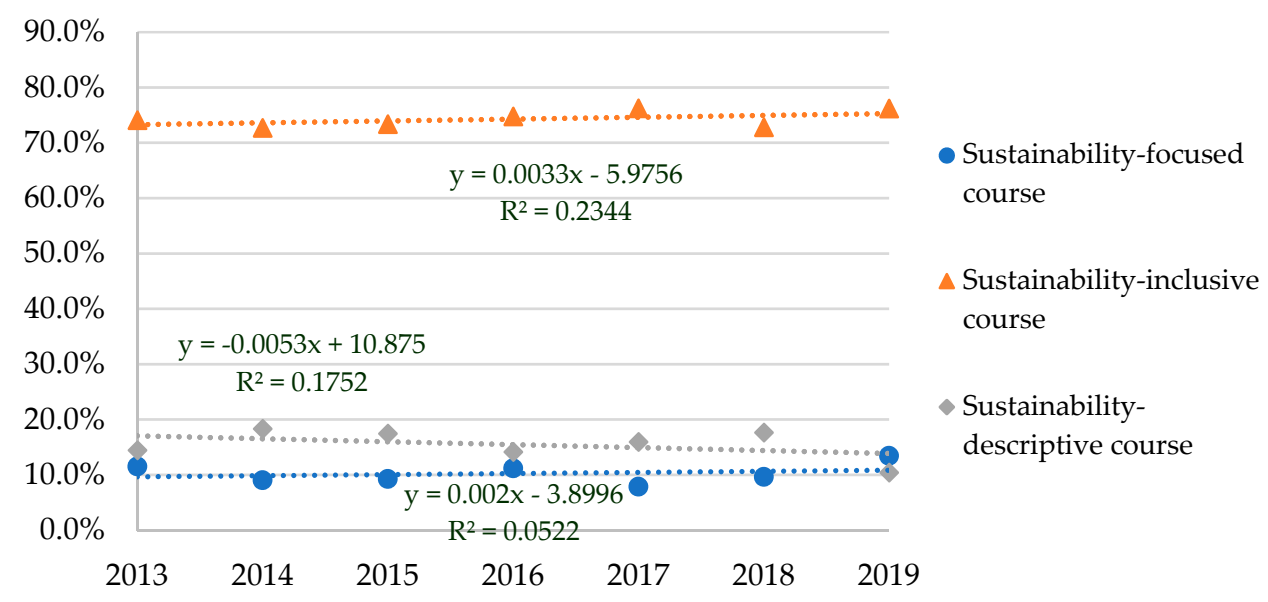

Figure 6. Annual trends in sustainability-focused, -inclusive and -descriptive courses.

\subsection{Analysis of Sustainability Courses by Degree Program}

The percentage of sustainability courses among undergraduate, graduate and MBA programs by year is shown in Table 3. The proportion of sustainability courses to all undergraduate and MBA courses for the seven-year period was $14.7 \%$, which was higher than that of sustainability courses to total courses in graduate programs (7.4\%). 
Table 3. Trends in the number and proportion of sustainability courses by degree program.

\begin{tabular}{|c|c|c|c|c|c|c|c|c|c|}
\hline \multicolumn{2}{|c|}{ Degree Program } & 2013 & 2014 & 2015 & 2016 & 2017 & 2018 & 2019 & All Years Combined \\
\hline \multirow{3}{*}{$\begin{array}{l}\text { Under- } \\
\text { graduate }\end{array}$} & Sustainability & 285 & 303 & 305 & 299 & 326 & 334 & 343 & 2195 \\
\hline & courses $(\%)$ & $(14.2 \%)$ & $(14.7 \%)$ & $(14.1 \%)$ & $(14.4 \%)$ & $(15.5 \%)$ & $(14.8 \%)$ & $(15.3 \%)$ & $(14.7 \%)$ \\
\hline & Total courses & 2009 & 2062 & 2160 & 2081 & 2108 & 2254 & 2242 & 14,916 \\
\hline \multirow{3}{*}{ Graduate } & Sustainability & 29 & 22 & 21 & 26 & 34 & 35 & 23 & 190 \\
\hline & courses $(\%)$ & $(7.1 \%)$ & $(6.4 \%)$ & $(5.8 \%)$ & $(7.1 \%)$ & $(9.4 \%)$ & $(9.4 \%)$ & $(6.3 \%)$ & $(7.4 \%)$ \\
\hline & Total courses & 409 & 342 & 362 & 365 & 363 & 374 & 363 & 2578 \\
\hline \multirow{3}{*}{ MBA } & Sustainability & 60 & 74 & 64 & 79 & 73 & 79 & 66 & 495 \\
\hline & & $(12.1 \%)$ & $(15.1 \%)$ & $(13.9 \%)$ & $(16.6 \%)$ & $(15.0 \%)$ & $(16.2 \%)$ & $(14.3 \%)$ & $(14.7 \%)$ \\
\hline & Total courses & 497 & 491 & 459 & 476 & 488 & 488 & 462 & 3361 \\
\hline
\end{tabular}

Note: proportions for sustainability courses by degree program were rounded to one decimal place.

In Figure 7, we present trend lines for the proportion of sustainability courses by degree program between 2013 and 2019. All undergraduate $\left(\beta: 0.0017, R^{2}=0.5019\right)$, graduate $\left(\beta: 0.0026, R^{2}=0.1431\right)$ and MBA $\left(\beta: 0.0035, R^{2}=0.2563\right)$ courses exhibited upward trend lines during the period of analysis.

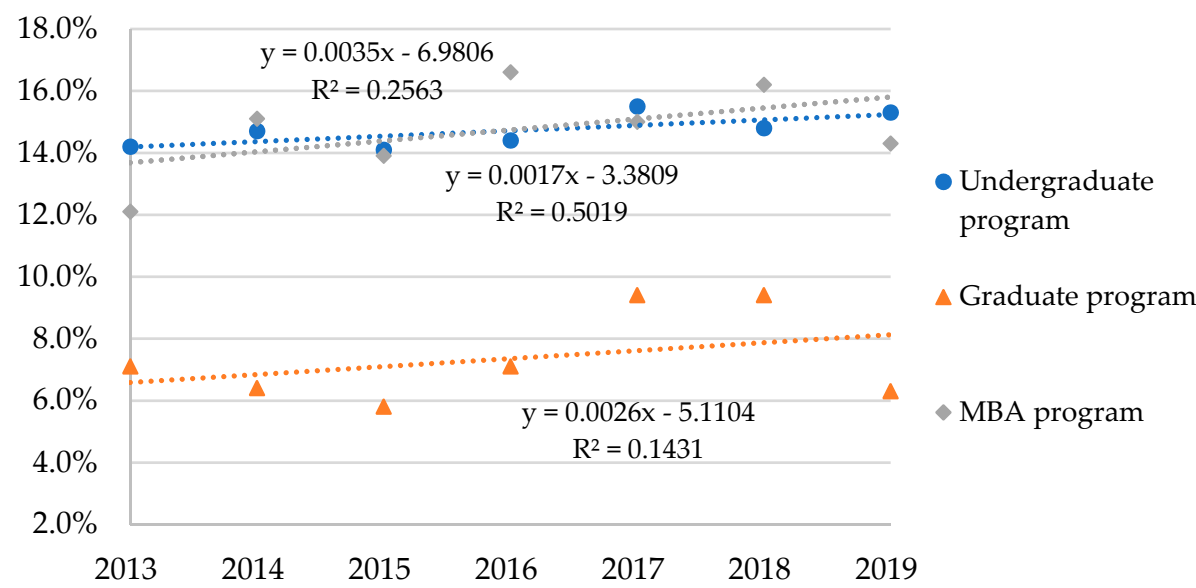

Figure 7. Trend lines for the proportion of sustainability course offerings by degree program.

Further analysis of sustainability courses for each degree program by sustainability course classification was conducted, with the results summarized in Table 4. As explained in our research design, undergraduate programs may offer more basic and introductory courses, graduate programs may provide more academic and advanced courses, and MBA programs may offer more practical and trending topics in Business Administration. As confirmed in our analysis, characteristics of sustainability courses offered by each degree program varied depending on unique course features of each program.

For undergraduate programs, the ratio of sustainability-inclusive courses to all courses for the seven-year period was $77.2 \%$, which was higher than that of graduate programs $(76.6 \%)$ and MBA programs $(60.8 \%)$. Since undergraduate programs may offer more introductory courses, sustainability issues were often dealt with as one of several topics in introductory courses. For graduate and MBA programs, the proportion of sustainabilityfocused courses to all courses for the seven-year period was $14.8 \%$ and $15.6 \%$, respectively, which was higher than that of undergraduate programs (8.6\%). Since graduate and MBA programs deal with more advanced topics in Business Administration, the percentage of courses covering sustainability issues in-depth may have been higher than that of undergraduate programs - even though the absolute number of courses for undergraduate programs was higher than that of graduate and MBA programs. 
Table 4. Sustainability courses by degree program based on sustainability course classification.

\begin{tabular}{|c|c|c|c|c|c|c|c|c|c|}
\hline Degree Program & Course Classification & 2013 & 2014 & 2015 & 2016 & 2017 & 2018 & 2019 & All Years Combined \\
\hline \multirow{4}{*}{ Under-graduate } & Focused & $\begin{array}{c}23 \\
(8.1 \%)\end{array}$ & $\begin{array}{c}22 \\
(7.3 \%)\end{array}$ & $\begin{array}{c}23 \\
(7.5 \%)\end{array}$ & $\begin{array}{c}29 \\
(9.7 \%)\end{array}$ & $\begin{array}{c}23 \\
(7.1 \%)\end{array}$ & $\begin{array}{c}27 \\
(8.1 \%)\end{array}$ & $\begin{array}{c}43 \\
(12.5 \%)\end{array}$ & $\begin{array}{c}190 \\
(8.6 \%)\end{array}$ \\
\hline & Inclusive & $\begin{array}{c}219 \\
(76.8 \%)\end{array}$ & $\begin{array}{c}234 \\
(77.2 \%)\end{array}$ & $\begin{array}{c}234 \\
(76.7 \%)\end{array}$ & $\begin{array}{c}230 \\
(76.9 \%)\end{array}$ & $\begin{array}{c}253 \\
(77.6 \%)\end{array}$ & $\begin{array}{c}252 \\
(75.4 \%) \\
\end{array}$ & $\begin{array}{c}272 \\
(79.3 \%) \\
\end{array}$ & $\begin{array}{c}1694 \\
(77.2 \%) \\
\end{array}$ \\
\hline & Descriptive & $\begin{array}{c}43 \\
(15.1 \%) \\
\end{array}$ & $\begin{array}{c}47 \\
(15.5 \%) \\
\end{array}$ & $\begin{array}{c}48 \\
(15.7 \%) \\
\end{array}$ & $\begin{array}{c}40 \\
(13.4 \%) \\
\end{array}$ & $\begin{array}{c}50 \\
(15.3 \%) \\
\end{array}$ & $\begin{array}{c}55 \\
(16.5 \%) \\
\end{array}$ & $\begin{array}{c}28 \\
(8.2 \%)\end{array}$ & $\begin{array}{c}311 \\
(14.2 \%)\end{array}$ \\
\hline & Total & 285 & 303 & 305 & 299 & 326 & 334 & 343 & 2195 \\
\hline \multirow{4}{*}{ Graduate } & Focused & $\begin{array}{c}8 \\
(27.6 \%) \\
\end{array}$ & $\begin{array}{c}2 \\
(9.1 \%)\end{array}$ & $\begin{array}{c}2 \\
(9.5 \%) \\
\end{array}$ & $\begin{array}{c}7 \\
(26.9 \%) \\
\end{array}$ & $\begin{array}{c}4 \\
(11.8 \%) \\
\end{array}$ & $\begin{array}{c}5 \\
(14.3 \%) \\
\end{array}$ & $\begin{array}{c}1 \\
(4.3 \%)\end{array}$ & $\begin{array}{c}29 \\
(14.8 \%) \\
\end{array}$ \\
\hline & Inclusive & $\begin{array}{c}20 \\
(69.0 \%)\end{array}$ & $\begin{array}{c}17 \\
(77.3 \%)\end{array}$ & $\begin{array}{c}19 \\
(90.5 \%)\end{array}$ & $\begin{array}{c}18 \\
(69.2 \%)\end{array}$ & $\begin{array}{c}27 \\
(79.4 \%)\end{array}$ & $\begin{array}{c}24 \\
(68.6 \%)\end{array}$ & $\begin{array}{c}19 \\
(82.6 \%)\end{array}$ & $\begin{array}{c}144 \\
(76.6 \%)\end{array}$ \\
\hline & Descriptive & $\begin{array}{c}1 \\
(3.4 \%)\end{array}$ & $\begin{array}{c}3 \\
(13.6 \%) \\
\end{array}$ & $\begin{array}{c}0 \\
(0.0 \%)\end{array}$ & $\begin{array}{c}1 \\
(3.8 \%)\end{array}$ & $\begin{array}{c}3 \\
(8.8 \%) \\
\end{array}$ & $\begin{array}{c}6 \\
(17.1 \%) \\
\end{array}$ & $\begin{array}{c}3 \\
(13.0 \%) \\
\end{array}$ & $\begin{array}{c}17 \\
(8.6 \%)\end{array}$ \\
\hline & Total & 29 & 22 & 21 & 26 & 34 & 35 & 23 & 190 \\
\hline \multirow{4}{*}{ MBA } & Focused & $\begin{array}{c}12 \\
(20.0 \%)\end{array}$ & $\begin{array}{c}12 \\
(16.2 \%)\end{array}$ & $\begin{array}{c}11 \\
(17.2 \%)\end{array}$ & $\begin{array}{c}9 \\
(11.4 \%)\end{array}$ & $\begin{array}{c}7 \\
(9.6 \%)\end{array}$ & $\begin{array}{c}11 \\
(13.9 \%)\end{array}$ & $\begin{array}{c}14 \\
(21.2 \%)\end{array}$ & $\begin{array}{c}76 \\
(15.6 \%)\end{array}$ \\
\hline & Inclusive & $\begin{array}{c}38 \\
(63.3 \%) \\
\end{array}$ & $\begin{array}{c}39 \\
(52.7 \%) \\
\end{array}$ & $\begin{array}{c}33 \\
(51.6 \%) \\
\end{array}$ & $\begin{array}{c}54 \\
(68.4 \%) \\
\end{array}$ & $\begin{array}{c}50 \\
(68.5 \%) \\
\end{array}$ & $\begin{array}{c}50 \\
(63.3 \%) \\
\end{array}$ & $\begin{array}{c}38 \\
(57.6 \%) \\
\end{array}$ & $\begin{array}{c}302 \\
(60.8 \%)\end{array}$ \\
\hline & Descriptive & $\begin{array}{c}10 \\
(16.7 \%)\end{array}$ & $\begin{array}{c}23 \\
(31.1 \%)\end{array}$ & $\begin{array}{c}20 \\
(31.3 \%)\end{array}$ & $\begin{array}{c}16 \\
(20.3 \%)\end{array}$ & $\begin{array}{c}16 \\
(21.9 \%)\end{array}$ & $\begin{array}{c}18 \\
(22.8 \%)\end{array}$ & $\begin{array}{c}14 \\
(21.2 \%)\end{array}$ & $\begin{array}{c}117 \\
(23.6 \%)\end{array}$ \\
\hline & Total & 60 & 74 & 64 & 79 & 73 & 79 & 66 & 495 \\
\hline
\end{tabular}

Note: proportions for sustainability courses were rounded to one decimal place.

\subsection{Discussion and Limitations}

Findings from this study indicate that we have seen an increase in the absolute number and proportion of sustainability courses in Korean business schools over the past seven years (from 2013-2019). During our period of analysis, the most prominent sustainability keywords were ethics ("eth") and corporate social responsibility ("CSR"). Aside from courses that included these two keywords, contents for other courses focused on a single sustainability keyword rather than linking sustainability keywords together. In addition, most courses that reflected sustainability keywords did so by allocating a few weeks to sustainability issues (sustainability-inclusive), rather than sustainability constituting the major theme of the course (sustainability-focused). On a positive note, a gradual decrease in sustainability-descriptive courses suggests that business schools are making conscious efforts to embed sustainability more substantively into the curriculum.

While the gradual increase in sustainability-related courses in Korean business schools can be seen as a positive trend, findings from our keyword and course program analysis indicate that rather than receiving an integrated and comprehensive curriculum on sustainability, students may be subject to a fragmented learning environment. This is particularly the case as there are few sustainability courses that are required major courses. For example, we found that introductory courses at the undergraduate level were predominantly sustainability-inclusive, while there was a higher percentage of sustainability-focused courses among business theory and practice courses at the graduate and MBA levels. Thus, in addition to business schools offering courses on specific sustainability keywords and recent trends, introductory courses in sustainability theory as functional (required) major courses may help provide a stronger foundation for business students going forward. Required introductory courses in sustainability theory may also be able to supplement the undergraduate curriculum while additional sustainability-related courses that focus on trends and keywords can further enhance the graduate/MBA programs.

Although we have highlighted several contributions of our research to the academic literature, this study was not without its limitations. First, this paper investigated whether and to what extent sustainability themes were integrated among Business Administration 
courses that had a publicly available course syllabus. Although most courses that did not have a syllabus available were thesis-related research courses or practicums, some functional major courses did not have syllabi available for download on their respective university websites. As such, it is possible that our analysis may reflect an artificially high percentage of courses that integrate sustainability into the curriculum. In addition, our findings are also limited as they take each course syllabus at face value. As syllabi are often subject to change, this does not take into account any changes in the syllabus that may have either reduced or increased learning time allocated to sustainability themes.

Second, there is very little research that can place our findings in a comparative perspective. For example, while Brugmann et al. [2] highlight that the maximum percentage of undergraduate courses in Canada that represent sustainability course offerings is $32 \%$ (with $1 \%$ being the minimum and $10 \%$ being the median), additional quantitative data on other regions is difficult to find. In addition, a critical discussion on whether a higher percentage of sustainability courses necessarily suggests better understanding and implementation of sustainability in a business context would further enrich the debate. To address this limitation, future research can attempt a global comparative analysis (alongside a fruitful discussion of actual understanding of sustainability issues) that would help to gauge the level of sustainability integration across a wider range of countries.

Third, while this research was able to show a general increase in sustainability integration over time, it was unable to identify clear determinants. These may include macro changes, such as policy changes, global/external pressures and university/corporate initiatives, or micro-level factors such as personal interests of the teaching faculty or student demand for sustainability-related courses. For example, a sudden spike in "social venture" courses (under "social value," "SV") in 2019 meant that the proportion of sustainabilityrelated courses jumped two-fold year-on-year to $11.6 \%$. Although identifying specific determinants behind these changes is beyond the scope of this paper, one contributing factor may have been the active push by corporations (such as SK Group and its Chairman, Chey Tae-won) in advocating "social value" over the past few years. These efforts culminated in the launch of Social Value Connect (SOVAC) in 2019, hosted as an offline event and attended by more than 4000 entrepreneurs, non-profits, students and citizens [58]. In addition, a budding generation of social entrepreneurs (particularly centered around Seongdong-gu in eastern Seoul) and the need to equip young ventures may have also served as an impetus for universities to support students during their studies [59]. As changes in blending sustainability in the curriculum may also be due to shifts in university agendas and even government initiatives, it may be worthwhile to uncover determinants behind these changes to accelerate further integration of sustainability in the curriculum.

Fourth, our sample study focused on top-ranked business schools in Korea, which collectively may be ahead of the curve when it comes to offering sustainability-related courses. As such, findings may not be representative of the average Korean business school. To test whether trends identified in this study reflect a comprehensive picture, future studies may utilize random sampling and compare results found in this analysis.

Lastly, and perhaps most importantly, we were unable to test whether students' understanding of sustainability issues and, ultimately, behavior actually changed as a result of taking the course. This also includes an in-depth investigation of teaching methods by lecturers, with particular attention to learning objectives, methods of engagement in sustainability issues as well as challenges to blending sustainability in the curriculum. As such, future research may help test the effectiveness of sustainability learning at both the undergraduate and graduate levels (and from the perspective of both students and lecturers), particularly as it relates to course contents and teaching methods.

\section{Conclusions}

To address whether the integration of sustainability-related courses at business schools has reflected the urgency of sustainability issues raised in industry and in academia, this paper examined to what extent Korean business schools have been incorporating 
sustainability-linked themes in the curriculum. This study provided a unique, in-depth review of the state of sustainability education at Korean business schools through an analysis of three major areas: (1) sustainability keywords; (2) course classifications; and (3) degree program.

Based on a review of 20,507 course syllabi from ten sample universities between 2013 and 2019, we note an increase in the absolute number and proportion of sustainabilitylinked courses in Korean business schools, increasing from 12.9\% of total courses in 2013 to $14.7 \%$ in 2019. In terms of keywords, the most prominent sustainability keywords were "ethics" and "corporate social responsibility." Regarding course classifications, most courses in our study reflected sustainability keywords by allocating a few weeks to sustainability issues (sustainability-inclusive) rather than sustainability serving as the major theme of the course (sustainability-focused). Lastly, in terms of degree program, sustainability-linked courses accounted for nearly $15 \%$ of total courses at the undergraduate and MBA levels, respectively, and just $7 \%$ of graduate (Master's/Ph.D.) programs in Business Administration.

While our findings suggest overall progress in incorporating sustainability themes in business schools, course offerings are fragmented and generally focus on a narrow concept of ethics rather than constituting a comprehensive curriculum that weaves sustainability throughout functional majors. In addition to several limitations raised in the previous section, additional analysis on whether learning outcomes are actually achieved as a result of taking sustainability-linked courses (and not just assuming that more courses mean more sustainability awareness) would further supplement this paper's findings.

Author Contributions: Conceptualization, H.J.; methodology, H.J. and S.M.; validation, H.J. and S.M.; formal analysis, H.J. and S.M.; data curation, S.M.; writing-original draft preparation, H.J.; writing-review and editing, H.J. and S.M.; visualization, S.M.; project administration, H.J. All authors have read and agreed to the published version of the manuscript.

Funding: This research received no external funding.

Institutional Review Board Statement: Not applicable.

Informed Consent Statement: Not applicable.

Data Availability Statement: The data presented in this study are available on request from the corresponding author. While the data is publicly available, providing the links would reveal the identity of universities analyzed in this study and have thus been excluded from this statement.

Acknowledgments: We would like to express thanks to Minh Thuy Pham for her support in collecting data.

Conflicts of Interest: The authors declare no conflict of interest.

Appendix A Trends in the Proportion of Sustainability Keyword Codes (2013-2019)

Table A1. Trends in the proportion of sustainability keyword codes (2013-2019).

\begin{tabular}{cllllllll}
\hline Keyword Code & $\mathbf{2 0 1 3}$ & $\mathbf{2 0 1 4}$ & $\mathbf{2 0 1 5}$ & $\mathbf{2 0 1 6}$ & $\mathbf{2 0 1 7}$ & $\mathbf{2 0 1 8}$ & $\mathbf{2 0 1 9}$ & All Years Combined \\
\hline eth & $51.3 \%$ & $51.6 \%$ & $52.6 \%$ & $46.5 \%$ & $51.5 \%$ & $47.3 \%$ & $45.4 \%$ & $49.4 \%$ \\
eth.CSR & $17.9 \%$ & $16.0 \%$ & $13.8 \%$ & $17.6 \%$ & $14.3 \%$ & $17.0 \%$ & $14.6 \%$ & $15.9 \%$ \\
CSR & $13.9 \%$ & $15.0 \%$ & $14.9 \%$ & $13.6 \%$ & $9.2 \%$ & $8.7 \%$ & $9.5 \%$ & $12.0 \%$ \\
SV & $2.7 \%$ & $4.0 \%$ & $3.6 \%$ & $5.0 \%$ & $4.8 \%$ & $5.8 \%$ & $11.6 \%$ & $5.5 \%$ \\
SB & $4.0 \%$ & $4.0 \%$ & $4.1 \%$ & $2.7 \%$ & $3.0 \%$ & $6.3 \%$ & $3.7 \%$ & $4.0 \%$ \\
CSR.SB & $1.3 \%$ & $0.8 \%$ & $1.3 \%$ & $2.7 \%$ & $3.2 \%$ & $2.2 \%$ & $2.1 \%$ & $2.0 \%$ \\
eth.CSR.SB & $0.3 \%$ & $1.5 \%$ & $1.3 \%$ & $2.0 \%$ & $3.2 \%$ & $2.0 \%$ & $2.1 \%$ & $1.8 \%$ \\
env & $2.4 \%$ & $1.8 \%$ & $1.3 \%$ & $1.2 \%$ & $1.6 \%$ & $2.2 \%$ & $1.2 \%$ & $1.7 \%$ \\
CSR.SV & $0.8 \%$ & $0.8 \%$ & $1.3 \%$ & $1.0 \%$ & $2.3 \%$ & $2.5 \%$ & $1.4 \%$ & $1.2 \%$ \\
eth.CSR.SV & $0.5 \%$ & $0.3 \%$ & $0.8 \%$ & $1.0 \%$ & $1.8 \%$ & $1.6 \%$ & $2.3 \%$ & $0.7 \%$ \\
eth.SB & $0.8 \%$ & $1.0 \%$ & $1.0 \%$ & $0.7 \%$ & $0.5 \%$ & $0.4 \%$ & $0.7 \%$ & $0.6 \%$ \\
SV.fin & $0.0 \%$ & $0.0 \%$ & $0.5 \%$ & $1.5 \%$ & $0.9 \%$ & $0.7 \%$ & $0.7 \%$ & $0.5 \%$ \\
eth.CSR.SV.env & $0.8 \%$ & $0.5 \%$ & $0.5 \%$ & $1.0 \%$ & $0.2 \%$ & $0.4 \%$ & $0.2 \%$ & $0.3 \%$ \\
eth.CSR.env & $0.5 \%$ & $0.5 \%$ & $0.8 \%$ & $0.2 \%$ & $0.0 \%$ & $0.4 \%$ & $0.0 \%$ & \\
\hline
\end{tabular}


Table A1. Cont.

\begin{tabular}{|c|c|c|c|c|c|c|c|c|}
\hline Keyword Code & 2013 & 2014 & 2015 & 2016 & 2017 & 2018 & 2019 & All Years Combined \\
\hline eth.CSR.env.SB & $0.0 \%$ & $0.0 \%$ & $0.3 \%$ & $0.0 \%$ & $0.5 \%$ & $0.7 \%$ & $0.5 \%$ & $0.3 \%$ \\
\hline CSR.SV.fin.SB & $0.3 \%$ & $0.3 \%$ & $0.0 \%$ & $0.2 \%$ & $0.0 \%$ & $0.2 \%$ & $0.7 \%$ & $0.2 \%$ \\
\hline CSR.SV.SB & $0.3 \%$ & $0.0 \%$ & $0.0 \%$ & $0.2 \%$ & $0.5 \%$ & $0.4 \%$ & $0.2 \%$ & $0.2 \%$ \\
\hline eth.CSR.fin & $0.0 \%$ & $0.0 \%$ & $0.3 \%$ & $0.2 \%$ & $0.0 \%$ & $0.7 \%$ & $0.2 \%$ & $0.2 \%$ \\
\hline eth.CSR.SV.fin.SB & $0.5 \%$ & $0.8 \%$ & $0.3 \%$ & $0.0 \%$ & $0.0 \%$ & $0.0 \%$ & $0.0 \%$ & $0.2 \%$ \\
\hline CSR.env.SB & $0.5 \%$ & $0.3 \%$ & $0.0 \%$ & $0.0 \%$ & $0.0 \%$ & $0.0 \%$ & $0.5 \%$ & $0.2 \%$ \\
\hline CSR.SV.fin & $0.0 \%$ & $0.0 \%$ & $0.0 \%$ & $0.2 \%$ & $0.0 \%$ & $0.0 \%$ & $0.7 \%$ & $0.1 \%$ \\
\hline eth.CSR.SV.SB & $0.0 \%$ & $0.3 \%$ & $0.0 \%$ & $0.5 \%$ & $0.2 \%$ & $0.0 \%$ & $0.0 \%$ & $0.1 \%$ \\
\hline CSR.env & $0.0 \%$ & $0.0 \%$ & $0.0 \%$ & $0.5 \%$ & $0.5 \%$ & $0.0 \%$ & $0.0 \%$ & $0.1 \%$ \\
\hline SV.SB & $0.0 \%$ & $0.0 \%$ & $0.0 \%$ & $0.2 \%$ & $0.0 \%$ & $0.0 \%$ & $0.5 \%$ & $0.1 \%$ \\
\hline CSR.SV.env.fin.SB & $0.0 \%$ & $0.3 \%$ & $0.0 \%$ & $0.0 \%$ & $0.0 \%$ & $0.2 \%$ & $0.2 \%$ & $0.1 \%$ \\
\hline fin & $0.0 \%$ & $0.0 \%$ & $0.5 \%$ & $0.0 \%$ & $0.0 \%$ & $0.2 \%$ & $0.0 \%$ & $0.1 \%$ \\
\hline CSR.env.fin.SB & $0.0 \%$ & $0.0 \%$ & $0.0 \%$ & $0.5 \%$ & $0.2 \%$ & $0.0 \%$ & $0.0 \%$ & $0.1 \%$ \\
\hline eth.CSR.SV.env.fin.SB & $0.3 \%$ & $0.3 \%$ & $0.3 \%$ & $0.0 \%$ & $0.0 \%$ & $0.0 \%$ & $0.0 \%$ & $0.1 \%$ \\
\hline eth.SV.SB & $0.3 \%$ & $0.0 \%$ & $0.3 \%$ & $0.0 \%$ & $0.2 \%$ & $0.0 \%$ & $0.0 \%$ & $0.1 \%$ \\
\hline eth.CSR.fin.SB & $0.0 \%$ & $0.0 \%$ & $0.0 \%$ & $0.0 \%$ & $0.0 \%$ & $0.0 \%$ & $0.5 \%$ & $0.1 \%$ \\
\hline CSR.SV.env.SB & $0.0 \%$ & $0.0 \%$ & $0.0 \%$ & $0.0 \%$ & $0.0 \%$ & $0.0 \%$ & $0.5 \%$ & $0.1 \%$ \\
\hline SV.env.SB & $0.3 \%$ & $0.0 \%$ & $0.0 \%$ & $0.0 \%$ & $0.0 \%$ & $0.0 \%$ & $0.2 \%$ & $0.1 \%$ \\
\hline fin.SB & $0.0 \%$ & $0.0 \%$ & $0.0 \%$ & $0.2 \%$ & $0.2 \%$ & $0.0 \%$ & $0.0 \%$ & $0.1 \%$ \\
\hline eth.SV & $0.0 \%$ & $0.0 \%$ & $0.0 \%$ & $0.2 \%$ & $0.2 \%$ & $0.0 \%$ & $0.0 \%$ & $0.1 \%$ \\
\hline eth.CSR.SV.fin & $0.0 \%$ & $0.3 \%$ & $0.0 \%$ & $0.0 \%$ & $0.0 \%$ & $0.0 \%$ & $0.0 \%$ & $0.0 \%$ \\
\hline eth.env & $0.3 \%$ & $0.0 \%$ & $0.0 \%$ & $0.0 \%$ & $0.0 \%$ & $0.0 \%$ & $0.0 \%$ & $0.0 \%$ \\
\hline env.fin.SB & $0.0 \%$ & $0.0 \%$ & $0.3 \%$ & $0.0 \%$ & $0.0 \%$ & $0.0 \%$ & $0.0 \%$ & $0.0 \%$ \\
\hline eth.env.SB & $0.0 \%$ & $0.0 \%$ & $0.3 \%$ & $0.0 \%$ & $0.0 \%$ & $0.0 \%$ & $0.0 \%$ & $0.0 \%$ \\
\hline CSR.fin & $0.0 \%$ & $0.0 \%$ & $0.0 \%$ & $0.0 \%$ & $0.2 \%$ & $0.0 \%$ & $0.0 \%$ & $0.0 \%$ \\
\hline env.SB & $0.0 \%$ & $0.0 \%$ & $0.0 \%$ & $0.0 \%$ & $0.2 \%$ & $0.0 \%$ & $0.0 \%$ & $0.0 \%$ \\
\hline SV.fin.SB & $0.0 \%$ & $0.0 \%$ & $0.0 \%$ & $0.0 \%$ & $0.2 \%$ & $0.0 \%$ & $0.0 \%$ & $0.0 \%$ \\
\hline Total & $\begin{array}{l}100 \% \\
(374)\end{array}$ & $\begin{array}{l}100 \% \\
(399)\end{array}$ & $\begin{array}{l}100 \% \\
(390)\end{array}$ & $\begin{array}{l}100 \% \\
(404)\end{array}$ & $\begin{array}{l}100 \% \\
(433)\end{array}$ & $\begin{array}{l}100 \% \\
(448)\end{array}$ & $\begin{array}{l}100 \% \\
(432)\end{array}$ & $\begin{array}{l}100 \% \\
(2880)\end{array}$ \\
\hline
\end{tabular}

Proportions for sustainability keyword codes were rounded to one decimal place. Sustainability keyword codes are listed in order (highest to lowest percentage) of sustainability keyword codes over the past seven years (2013-2019).

\section{Appendix B Sample Syllabus Text by Sustainability Course Classification}

Table A2. Sample syllabus text by sustainability course classification.

\begin{tabular}{|c|c|c|}
\hline Sustainability-Focused & Sustainability-Inclusive & Sustainability-Descriptive \\
\hline $\begin{array}{l}\text { Corporate Social Responsibility } \\
\text { (MBA course) } \\
\text { Course Schedule } \\
\text { Week 1. Course introduction; Understanding CSR } \\
\text { Week 2. Strategic CSR, and creating shared value } \\
\text { (CSV) } \\
\text { Week 3. Stakeholder management } \\
\text { Week 4. Socially responsible investment } \\
\text { Week 5. Responsible human resource management } \\
\text { Week 6. Economic responsibility and market } \\
\text { competition } \\
\text { Week 7. Responsibility in financial market } \\
\text { Week } 8 \text {. Global supply chain and ethical } \\
\text { responsibility } \\
\text { Week } 9 \text {. Protecting customers } \\
\text { Week 10. Sustainable management } \\
\text { Week 11. Social enterprise } \\
\text { Week } 12 \text {. Managing controversies } \\
\text { Week 13. Final exam } \\
\text { Week } 14 \text {. Group presentations } \\
\text { Week 15. Group presentations } \\
\text { Week 16. Group presentations } \\
\text { Sustainability keywords are included in nine weeks out of } \\
\text { a total of } 16 \text { weeks (over } 50 \% \text { of weekly topics). Therefore, } \\
\text { it can be said that the primary and explicit focus of this } \\
\text { course is on sustainability. }\end{array}$ & $\begin{array}{l}\text { Organizational Theory and Behavior } \\
\text { (Graduate course) } \\
\text { Course Schedule } \\
\text { Week } 1 \text {. Course overview and the importance of } \\
\text { Organizational Behavior } \\
\text { Week } 2 \text {. Emotions and moods in the workplace } \\
\text { Week } 3 \text {. Personality } \\
\text { Week } 4 \text {. Leadership } \\
\text { Week } 5 \text {. Entrepreneurship } \\
\text { Week } 6 \text {. Motivation in the workplace } \\
\text { Week } 7 \text {. Ethics and decision-making } \\
\text { Week } 8 \text {. Introduction to negotiation basics } \\
\text { Week } 9 \text {. Power, persuasion, status Week 10. Power, } \\
\text { persuasion, status } \\
\text { Week } 11 \text {. Groups and teams } 1 \\
\text { Week } 12 \text {. Groups and teams } 2 \\
\text { Week } 13 \text {. Culture } \\
\text { Week } 14 \text {. Crisis management } \\
\text { Week } 15 \text {. Team presentations } \\
\text { Week } 16 \text {. Course wrap-up and debrief } \\
\text { Sustainability keywords are included for one week (week } 7 \text { ) } \\
\text { out of a total } 16 \text { weeks (less than } 50 \% \text { of weekly subjects). } \\
\text { Thus, it can be said that the primary and explicit focus of } \\
\text { this course is not on sustainability, but sustainability } \\
\text { issues are clearly covered in the course. }\end{array}$ & $\begin{array}{l}\text { Production and Operations } \\
\text { Management } \\
\text { (MBA course) } \\
\text { Course Objective } \\
\text { After completing this course, } \\
\text { students will be able to achieve } \\
\text { the following learning goals: } \\
\text { [ ... ] } \\
\text { - Learn OM's roles and } \\
\text { responsibility regarding } \\
\text { sustainable business practices } \\
\text { and corporate social } \\
\text { responsibility. } \\
\text { Although sustainability keywords are } \\
\text { not included in the course schedule or } \\
\text { main references, the course objective } \\
\text { indicates that this course helps } \\
\text { understand sustainability-related } \\
\text { issues (sustainable business practice, } \\
\text { CSR). }\end{array}$ \\
\hline
\end{tabular}


Table A2. Cont.

\begin{tabular}{|c|c|c|}
\hline Sustainability-Focused & Sustainability-Inclusive & Sustainability-Descriptive \\
\hline $\begin{array}{l}\text { Sustainable Management } \\
\text { (Undergraduate course) } \\
\text { Course Schedule } \\
\text { Week 1. Introduction } \\
\text { Week 2. Business Ethics, why is it needed? } \\
\text { Week 3. The theory of business ethics } \\
\text { Week 4. Corporate Social Responsibility and } \\
\text { Business Strategy } \\
\text { Week 5. Analyses on stakeholder and company risk } \\
\text { management } \\
\text { Week 6. Ethical management of multinational } \\
\text { companies } \\
\text { Week 7. Ethics of environmental management } \\
\text { Week } 8 \text {. Mid-term Examination } \\
\text { Week 9. Ethics in Human Resource Management } \\
\text { Week 10. Ethics in Marketing Management } \\
\text { Week 11. Ethics in Accounting and Financial } \\
\text { Management } \\
\text { Week 12. Ethics in Production and Product } \\
\text { Management } \\
\text { Week 13. Ethics in Information Management } \\
\text { Week 14. Team Project presentation } \\
\text { Week 15. Team Project presentation } \\
\text { Week 16. Final Exam } \\
\text { Sustainability keywords are included in ten weeks out of a } \\
\text { total of } 16 \text { weeks (over } 50 \% \text { of weekly topics). Therefore, it } \\
\text { can be said that the primary and explicit focus of this } \\
\text { course is on sustainability. }\end{array}$ & $\begin{array}{l}\text { Modern Enterprise and Business Ethics } \\
\text { (Undergraduate course) } \\
\text { Course Schedule } \\
\text { Week 1. Fundamentals of a company } \\
\text { Week 2. Nature of business environment } \\
\text { Week 3. Nature and importance of decision-making } \\
\text { Week } 4 \text {. Management implications of planning } \\
\text { activities } \\
\text { Week 5. Organization's structure and culture } \\
\text { Week 6. Fundamentals of organizational change and } \\
\text { innovation } \\
\text { Week } 7 \text {. Personal/collective management of an } \\
\text { enterprise } \\
\text { Week } 8 \text {. Mid-term } \\
\text { Week 9. Motivation } \\
\text { Week 10. Significance and nature of leadership } \\
\text { Week 11. Nature of communication and its impact on } \\
\text { corporate management } \\
\text { Week 12. Fundamentals of corporate ethics } \\
\text { Week 13. Inter-relationship between production } \\
\text { management and corporate ethics } \\
\text { Week 14. Inter-relationship between financial } \\
\text { management and corporate ethics } \\
\text { Week 15. Inter-relationship between marketing } \\
\text { and corporate ethics } \\
\text { Week 16. Final Exam } \\
\text { Sustainability keywords are included in four weeks (week } \\
\text { 12-15) out of a total of } 16 \text { weeks (less than } 50 \% \text { of weekly } \\
\text { subjects). Thus, it can be said that the primary and } \\
\text { explicit focus of this course is not on sustainability, but } \\
\text { sustainability issues are clearly addressed in the course. }\end{array}$ & $\begin{array}{l}\text { Marketing Management } \\
\text { (Undergraduate course) } \\
\text { Course Description } \\
\text { The course focuses on covering } \\
\text { key marketing concepts and } \\
\text { processes [ ... ] Special topics } \\
\text { such as ethical issues in } \\
\text { marketing, corporate social } \\
\text { responsibility, and technological } \\
\text { impacts on marketing are also } \\
\text { integrated in discussion. } \\
\text { Although sustainability keywords are } \\
\text { not included in the course schedule or } \\
\text { main references, the course } \\
\text { description indicates that this course } \\
\text { addresses sustainability-related issues } \\
\text { (ethics, CSR). }\end{array}$ \\
\hline
\end{tabular}

\section{References}

1. Sherman, D.J. Sustainability: What's the big idea? A strategy for transforming the higher education curriculum. Sustain. J. Rec 2008, 1, 188-195. [CrossRef]

2. Brugmann, R.; Côté, N.; Postma, N.; Shaw, E.A.; Pal, D.; Robinson, J.B. Expanding student engagement in sustainability: Using SDG-and CEL-focused inventories to transform curriculum at the University of Toronto. Sustainability 2019, 11, 530. [CrossRef]

3. Slater, D.J.; Dixon-Fowler, H.R. The future of the planet in the hands of MBAs: An examination of CEO MBA education and corporate environmental performance. Acad. Manag. Learn. Educ. 2010, 9, 429-441.

4. UN Documents. Report of the World Commission on Environment and Development: Our Common Future; UN: Geneva, Switzerland, 1987.

5. Moore, J. Seven recommendations for creating sustainability education at the university level. Int. J. Sustain. High. Educ. 2005, 6, 326-339. [CrossRef]

6. Bacon, C.M.; Mulvaney, D.; Ball, T.B.; DuPuis, E.M.; Gliessman, S.R.; Lipschutz, R.D.; Shakouri, A. The creation of an integrated sustainability curriculum and student praxis projects. Int. J. Sustain. High. Educ. 2011, 12, 193-208. [CrossRef]

7. Hill, L.M.; Wang, D. Integrating sustainability learning outcomes into a university curriculum. Int. J. Sustain. High. Educ. 2018, 19, 699-720. [CrossRef]

8. Wersun, A.; Dean, B.A.; Mills, R.; Perkiss, S.; Acosta, P.; Anastasiadis, S.; Gibbons, B.; Gonzalez-Perez, M.A.; Heithaus, T.; Jun, H.; et al. An exploration of student learning for sustainability through the WikiRate student engagement project. Int. J. Manag. Educ. 2019, 17, 1-12. [CrossRef]

9. Anastasiadis, S.; Perkiss, S.; Dean, B.A.; Bayerlein, L.; Gonzalez-Perez, M.A.; Wersun, A.; Acosta, P.; Jun, H.; Gibbons, B. Teaching sustainability: Complexity and compromises. J. Appl. Res. High. Educ. 2020, 13, 1-15. [CrossRef]

10. Wu, Y.C.J.; Huang, S.; Kuo, L.; Wu, W.H. Management education for sustainability: A web-based content analysis. Acad. Manag. Learn. Educ. 2010, 9, 520-531. [CrossRef]

11. Wu, Y.C.J.; Shen, J.P.; Kuo, T. An overview of management education for sustainability in Asia. Int. J. Sustain. High. Educ. 2015, 16, 341-353. [CrossRef]

12. Kasim, A. The need for business environmental and social responsibility in the tourism industry. Int. J. Hosp. Tour. Admin. 2006, 7, 1-22. [CrossRef]

13. Bryant, A.N.; Gayles, J.G.; Davis, H.A. The relationship between civic behavior and civic values: A conceptual model. Res. High. Educ. 2012, 53, 76-93. [CrossRef] 
14. Ghoshal, S. Bad management theories are destroying good management practices. Acad. Manag. Learn. Educ. 2005, 4, 75-91. [CrossRef]

15. George, R.J. Teaching business ethics: Is there a gap between rhetoric and reality? J. Bus. Ethics 1987, 6, 513-518. [CrossRef]

16. Bok, D.C. Can ethics be taught? Change 1976, 8, 26-30. [CrossRef]

17. Ponemon, L.A. Can ethics be taught in accounting? J. Account. Educ. 1993, 11, 185-209. [CrossRef]

18. Park, H.J. Can business ethics be taught? A new model of business ethics education. J. Bus. Ethics 1998, 17, 965-977. [CrossRef]

19. Gandz, J.; Hayes, N. Teaching business ethics. J. Bus. Ethics 1988, 7, 657-669. [CrossRef]

20. Oddo, A.R. A framework for teaching business ethics. J. Bus. Ethics 1997, 16, 293-297. [CrossRef]

21. Baetz, M.C.; Sharp, D.J. Integrating ethics content into the core business curriculum: Do core teaching materials do the job? J. Bus. Ethics 2004, 51, 53-62. [CrossRef]

22. Drucker, P.F. What is business ethics? Public Interest 1981, 63, 18.

23. Macfarlane, B.; Ottewill, R. Business ethics in the curriculum: Assessing the evidence from UK subject review. J. Bus. Ethics 2004, 54, 339-347. [CrossRef]

24. Lee, C.Y. Impacts of teaching business ethics in Korea. Teach. Bus. Ethics 1997, 1, 131-149. [CrossRef]

25. Carroll, A.B. The pyramid of corporate social responsibility: Toward the moral management of organizational stakeholders. Bus. Horiz. 1991, 34, 39-48. [CrossRef]

26. Vishwanathan, P.; van Oosterhout, H.; Heugens, P.P.; Duran, P.; Van Essen, M. Strategic CSR: A concept building meta-analysis. J. Manag. Stud. 2020, 57, 314-350. [CrossRef]

27. Matten, D.; Moon, J. Corporate social responsibility education in Europe. J. Bus. Ethics 2004, 54, 323-337. [CrossRef]

28. Setó-Pamies, D.; Domingo-Vernis, M.; Rabassa-Figueras, N. Corporate social responsibility in management education: Current status in Spanish universities. J. Manag. Organ. 2011, 17, 604. [CrossRef]

29. Jorge, M.L.; Peña, F.J.A. Determinants of corporate social responsibility and business ethics education in Spanish universities. Bus. Ethics Eur. Rev. 2014, 23, 139-153. [CrossRef]

30. Porter, M.E.; Kramer, M.R. Creating shared value. In Managing Sustainable Business; Springer: Dordrecht, Germany, 2019; pp. 323-346.

31. Crane, A.; Palazzo, G.; Spence, L.J.; Matten, D. Contesting the value of "creating shared value". Calif. Manag. Rev. 2014, 56, 130-153. [CrossRef]

32. Rusinko, C.A. Integrating sustainability in management and business education: A matrix approach. Acad. Manag. Learn. Educ. 2010, 9, 507-519.

33. Jamali, D.; Neville, B. Convergence versus divergence of CSR in developing countries: An embedded multi-layered institutional lens. J. Bus. Ethics 2011, 102, 599-621. [CrossRef]

34. Jamali, D.; Karam, C. Corporate social responsibility in developing countries as an emerging field of study. Int. J. Manag. Rev. 2018, 20, 32-61. [CrossRef]

35. Peredo, A.M.; McLean, M. Social entrepreneurship: A critical review of the concept. J. World Bus. 2006, 41, 56-65. [CrossRef]

36. Korea Social Enterprise Promotion Agency. Available online: https://www.socialenterprise.or.kr/social/ente/concept.do?m_ $\mathrm{cd}=\mathrm{E} 001$ (accessed on 10 January 2021). (In Korean).

37. Barnes, A.J.; Ferry, J.K. Creating a niche for the environment in the business school curriculum. Bus. Horiz. 1992, 35, 3-8. [CrossRef]

38. Benton, R. Does an environmental course in the business school make a difference? J. Environ. Educ. 1993, 24, 37-43. [CrossRef]

39. Mintu, A.T.; Lozada, H.R. Green marketing education: A call for action. Market. Educ. Rev. 1994, 4, 17-21. [CrossRef]

40. Iyer, E. The three faces of green advertising. J. Advert. 1995, 24, III-V. [CrossRef]

41. Ntanos, S.; Asonitou, S.; Kyriakopoulos, G.; Skordoulis, M.; Chalikias, M.; Arabatzis, G. Environmental sensitivity of business school students and their attitudes towards social and environmental accounting. In Strategic Innovative Marketing and Tourism; Springer: Cham, Switzerland, 2020; pp. 195-203.

42. Sparkes, R.; Cowton, C.J. The maturing of socially responsible investment: A review of the developing link with corporate social responsibility. J. Bus. Ethics 2004, 52, 45-57. [CrossRef]

43. Capelle-Blancard, G.; Monjon, S. Trends in the literature on socially responsible investment: Looking for the keys under the lamppost. Bus. Ethics Eur. Rev. 2012, 21, 239-250. [CrossRef]

44. Galema, R.; Plantinga, A.; Scholtens, B. The stocks at stake: Return and risk in socially responsible investment. J. Bank Financ. 2008, 32, 2646-2654. [CrossRef]

45. Williams, G. Some determinants of the socially responsible investment decision: A cross-country study. J. Behav. Financ. 2007, 8, 43-57. [CrossRef]

46. Amel-Zadeh, A.; Serafeim, G. Why and how investors use ESG information: Evidence from a global survey. Financ. Anal. J. 2018, 74, 87-103. [CrossRef]

47. Kotsantonis, S.; Pinney, C.; Serafeim, G. ESG integration in investment management: Myths and realities. Bank Am. J. Appl. Corp. Finance 2016, 28, 10-16.

48. Van Duuren, E.; Plantinga, A.; Scholtens, B. ESG integration and the investment management process: Fundamental investing reinvented. J. Bus. Ethics 2016, 138, 525-533. [CrossRef] 
49. Bridges, C.M.; Wilhelm, W.B. Going beyond green: The "why and how" of integrating sustainability into the marketing curriculum. J. Market. Manag. 2008, 30, 33-46. [CrossRef]

50. Fukukawa, K.; Shafer, W.E.; Lee, G.M. Values and attitudes toward social and environmental accountability: A study of MBA students. J. Bus. Ethics 2007, 71, 381-394. [CrossRef]

51. Nicholls, J.; Hair Jr, J.F.; Ragland, C.B.; Schimmel, K.E. Ethics, corporate social responsibility, and sustainability education in AACSB undergraduate and graduate marketing curricula: A benchmark study. J. Market. Educ. 2013, 35, 129-140. [CrossRef]

52. Kurpis, L.V.; Beqiri, M.S.; Helgeson, J.G. The effects of commitment to moral self-improvement and religiosity on ethics of business students. J. Bus. Ethics 2008, 80, 447-463. [CrossRef]

53. Christensen, L.J.; Peirce, E.; Hartman, L.P.; Hoffman, W.M.; Carrier, J. Ethics, CSR, and sustainability education in the Financial Times top 50 global business schools: Baseline data and future research directions. J. Bus. Ethics 2007, 73, 347-368. [CrossRef]

54. Kolb, M.; Fröhlich, L.; Schmidpeter, R. Implementing sustainability as the new normal: Responsible management education-From a private business school's perspective. Int. J. Manag. Educ. 2017, 15, 280-292. [CrossRef]

55. Corporate Knights. Available online: https://www.corporateknights.com/reports/better-world/business-schools-up-the-gradeon-sustainability-15731929/ (accessed on 20 December 2020).

56. Association for the Advancement of Sustainability in Higher Education (AASHE). STARS Technical Manual, Version 2.2. Available online: https: / / stars.aashe.org/resources-support/technical-manual/ (accessed on 6 July 2020).

57. Berger, S.; Canning, R.; Dolan, M.; Kurek, S.; Pilz, M.; Rachwal, T. Curriculum-making in pre-vocational education in the lower secondary school: A regional comparative analysis within Europe. J. Curr. Stud. 2012, 44, 679-701. [CrossRef]

58. Business Korea. Available online: http:/ / www.businesskorea.co.kr/news/articleView.html?idxno=32321 (accessed on 1 March 2021).

59. Pulse. Available online: https:/ / pulsenews.co.kr/view.php?year=2019\&no=934995 (accessed on 1 March 2021). 